Volume 13, No. 1, Juni 2014

ISSN 1411-514X (print)

ISSN 2355-7737 (online)

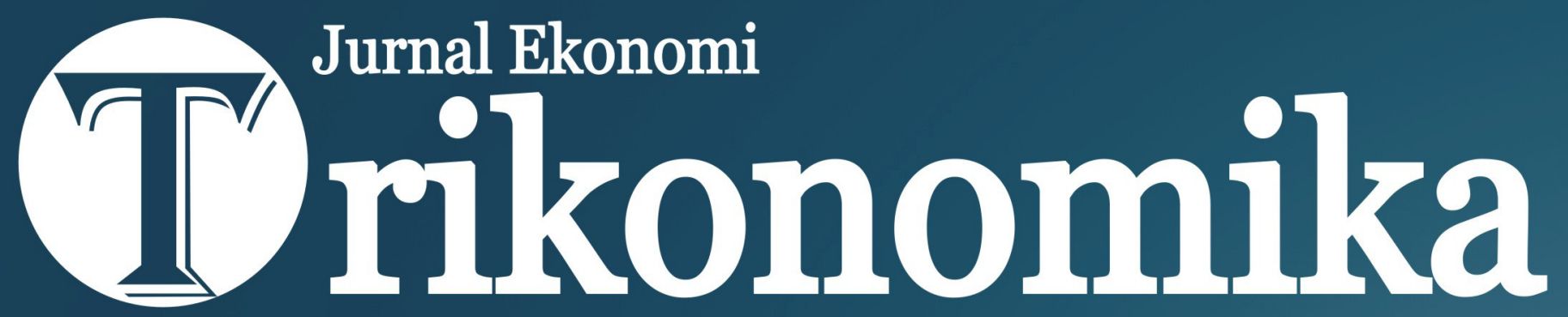




\section{DAFTAR ISI}

Trikonomika, Volume 13, No. 1, Juni 2014

Pengaruh Otonomi dan Akuntabilitas Perguruan Tinggi terhadap Kinerja Manajerial

Isnaeni Nurhayati ...

Keseimbangan Jangka Pendek dan Jangka Panjang Nilai Tukar Rupiah terhadap Dollar Amerika

Horas Djulius, Yudi Nurdiansyah

Kajian Kepemimpinan Transformasional, Komitmen Karyawan, Motivasi, Kepuasan Kerja, dan Kinerja Karyawan

Edy Saptono $21-48$

Pengaruh Kualitas Pelayanan terhadap Kepuasan Mahasiswa Program Ekstensi Fakultas Ekonomi Universitas Jambi

Yenny Yuniarti $49-61$

Determinan Profitabilitas Bank: Suatu Studi pada Bank yang Terdaftar di BEI

Jaja Suteja, Gerinata Ginting $62-77$

Faktor Determinan Minat Wirausaha Mahasiswa Fakultas Ekonomi dan Bisnis Universitas Negeri Gorontalo

Herwin Mopangga $78-90$

Pengaruh Upah dan Pengalaman Kerja terhadap Produktivitas Karyawan Kerajinan Ukiran Kabupaten Subang

Ardika Sulaeman $91-100$

Analisis Harga Saham dan Rata-Rata Abnormal Return Sebelum dan Sesudah Ex-Dividend Date (Studi pada Emiten Indeks Kompas-100)

Alvin Mulya Hidayati $101-107$

Pengaruh Manajemen Laba Akrual dengan Pendekatan Revenue Discretionary Model terhadap Kinerja Perusahaan

Sepriahangga Wahyu Windharta, Nurmala Ahmar $108-118$ 


\title{
Pengaruh Kualitas Pelayanan terhadap Kepuasan Mahasiswa Program Ekstensi Fakultas Ekonomi Universitas Jambi
}

\author{
Yenny Yuniarti \\ Fakultas Ekonomi Universitas Jambi \\ Jl. Raya Jambi - Muara Bulan KM. 15 Mendalo Darat, Jambi \\ E-Mail: yennyyuniarti@yahoo.co.id
}

\begin{abstract}
The phenomenon happening nowadays is that, colleges become commodities needed by society in order to improve people's lives. A quality college is literally seen by the public from its facilities and infrastructures as well as by the satisfaction of the students at that college or university. So the purpose of this study is to observe the effect of service quality on student satisfaction at the Extension Program Faculty of Economics, University of Jambi, either simultaneously or partially. The data used are primary and secondary data. Primary data were obtained from questionnaires disseminated to 100 students which were selected as research sample. The method used is descriptive method of verification, while the research tool used is path analysis. The result of this research shows that there is significant effect of service quality on student satisfaction both simultaneously (by 54.2\%) and partially. The partial effect on reliability is $19.98 \%$, responsiveness is $23.25 \%$, physical evidence is $25.34 \%$, empathy is $21.57 \%$, and assurance is $18.10 \%$.
\end{abstract}

Keywords: service quality, tangible, empathy, responsiveness, reliability, assurance, student satisaction.

\begin{abstract}
ABSTRAK
Fenomena yang terjadi saat ini, yaitu perguruan tinggi menjadi suatu komoditas yang dibutuhkan oleh masyarakat dalam upaya peningkatan taraf hidup masyarakat. Di mana perguruan tinggi yang berkualitas dilihat secara harfiah oleh masyarakat dari sarana dan prasarana yang dimiliki serta kepuasan mahasiswa yang berada di dalam lingkungan perguruan tinggi itu sendiri. Sehingga tujuan dari penelitian ini adalah untuk melihat pengaruh kualitas pelayanan terhadap kepuasan mahasiswa Program Ekstensi Fakultas Ekonomi Universitas Jambi baik secara simultan maupun parsial. Data yang digunakan adalah data primer dan sekunder. Di mana data primer diperoleh dari penyebaran kuisioner kepada 100 orang mahasiswa yang menjadi sampel penelitian. Metode penelitian yang digunakan adalah metode deskriptif verifikatif, sedangkan alat penelitian yang digunakan adalah analisis jalur. Hasil penelitian menunjukkan terdapat pengaruh signifikan dari kualitas pelayanan terhadap kepuasan mahasiswa baik secara simultan sebesar 54,2\% dan secara parsial masing-masing keandalan $19,98 \%$, daya tanggap $23,25 \%$, bukti fisik $25,34 \%$, empati $21,57 \%$, dan jaminan $18,10 \%$..
\end{abstract}

Kata Kunci: kualitas pelayanan, tangible, emphaty, responsiveness, realibity, assurance, dan kepuasan mahasiswa. 


\section{PENDAHULUAN}

Pendidikan merupakan sesuatu yang berlangsung secara berkelanjutan sejak seseorang masih berada dalam lingkungan keluarga. Pendidikan formal dimulai ketika seorang anak memasuki sekolah dasar sampai dengan perguruan tinggi. Perguruan tinggi merupakan lembaga pendidikan tinggi yang menghasilkan lulusan-lulusan yang ahli dalam berbagai bidang demi menjawab berbagai kebutuhan masyarakat, bangsa, dan Negara (Seniati, 2006).

Sektor pendidikan merupakan salah satu sektor yang paling penting dari ekonomi. Banyak negara sekarang pergeseran ekonomi mereka dari manufaktur ke sektor jasa. Pendidikan sektor adalah salah satu sektor jasa yang paling penting. Sektor pendidikan kini dianggap sama pentingnya dengan yang lain sektor ekonomi. Persaingan sekarang meningkat dengan di industri di sektor jasa. Peneliti dan akademisi yang menekankan perhatian mereka terhadap sektor pendidikan (Ahmed et al., 2010).

Seiring dengan meningkatnya peran perguruan tinggi dalam mendukung program pemerintah untuk meningkatkan kualitas hidup dengan memperoleh pendidikan yang layak, menuntut perguruan tinggi untuk terus-menerus meningkatkan kualitas pelayanan yang diberikan kepada mahasiswa sebagai stakeholder utama dari perguruan tinggi. Fenomena yang terjadi saat ini, yaitu perguruan tinggi menjadi suatu komoditas yang dibutuhkan oleh masyarakat dalam upaya peningkatan taraf hidup masyarakat. Di mana perguruan tinggi yang berkualitas dilihat secara harfiah oleh masyarakat dari sarana dan prasarana yang dimiliki, serta kepuasan mahasiswa yang berada di dalam lingkungan perguruan tinggi itu sendiri.

Universitas Jambi sebagai salah satu perguruan tinggi yang ada di Provinsi Jambi, saat ini memiliki10 (sepuluh) buah fakultas di mana salah satunya adalah Fakultas Ekonomi yang memiliki program non reguler atau program ekstensi yang diperuntukan bagi lulusan Sekolah Menengah Umum (SMU) sederajat yang tidak tertampung di program reguler dan juga diperuntukan bagi lulusan SMU sederajat yang telah bekerja, serta lulusan program Diploma III yang ingin melanjutkan hingga ke jenjang Strata 1. Saat ini program ekstensi ekonomi memiliki tiga program studi, yaitu Program Studi Ilmu Ekonomi dan Studi Pembangunan, Program Studi Manajemen, dan
Program Studi Akuntansi. Di mana jumlah mahasiswa dari ketiga program studi tersebut sebanyak 2.154 orang.

Semakin tingginya minat lulusan SMU sederajat yang ingin menempuh tingkat pendidikan strata satu di Program Ekstensi Fakultas Ekonomi mendorong program ekstensi untuk terus-menerus meningkatkan kualitas pelayanan yang diberikan kepada mahasiswa pada program tersebut. Kualitas pelayanan pada program ekstensi Fakultas Ekonomi tidak hanya berupa sarana dan prasarana yang dimiliki seperti ruang kuliah yang nyaman, ketersediaan alat-alat perkuliahan seperti infokus, serta laboratorium komputer sendiri, tetapi juga dari pelayanan yang diberikan oleh seluruh pengelola Program Ekstensi Fakultas Ekonomi, mulai dari karyawan yang mengatur parkir kendaraan, hingga ketua program ekstensi yang dibantu juga oleh sekretaris program ekstensi, ketua program studi dan sekretaris program studi, serta layanan akademik. Saat ini jumlah pengelola dan pegawai yang ada di Program Ekstensi Fakultas Ekonomi berjumlah 25 orang, yang terdiri atas 9 orang pengelola dan 16 orang pegawai. Di mana 16 orang pegawai terdiri dari 7 orang adalah Pegawai Negeri Sipil (PNS) yang diperbantukan pada program ini dan 9 orang pegawai kontrak.

Konsekuensinya penyedia layanan/jasa harus mampu membangun persepsi kepuasan pelanggan dengan melakukan inovasi-inovasi tertentu yang dapat secara langsung dan konsisten ditransfer ke pelanggannya (Olorunniwo et al, 2006). Penyedia layanan/jasa yang berorientasi pada kondisi pasar menurut Fitzsimmons and Fitzsimmons (2004) diklasifikasikan atas beberapa dimensi yaitu intangibility, differentiation, transformasi obyek, tipe pelanggan, dan komitmen manajemen perusahaan.

Salah satu cara untuk mempertahankan pelanggan menurut Fornell (1992) adalah dengan meningkatkan satisfaction yang ada. Faktor-faktor yang mempengaruhi satisfaction dapat diketahui bila perusahaan mengenal apa yang dibutuhkan pelanggan. Pengetahuan mengenai kebu-tuhan pelanggan sangat penting karena akan memberi warna atau suatu pemahaman yang lebih baik mengenai cara pelanggan mengartikan service quality (kualitas barang atau jasa) perusahaan.

Penelitian Prince dan Simon (2009) menyatakan bahwa terdapat dua hal yang menyebabkan perusahaan 
layanan/jasa untuk mengimplementasikan service quality dengan baik yaitu pertama, adanya tekanan dari pesaing, dimana pesaing selalu melakukan inovasi-inovasi yang menyebabkan perusahaan juga harus ikut melakukan inovasi, bila perusahaan tidak melakukan inovasi maka akan menyebabkan penurunan profit perusahaan disebabkan pelanggan akan berpindah ke pesaing.

Program Ekstensi Fakultas Ekonomi Universitas Jambi saat ini memiliki beberapa permasalahan yang dapat mengganggu proses belajar mengajar dan pemberian layanan akademik kepada mahasiswa. Permasalahan yang dihadapi antara lain kurangnya ruang kuliah, dikarenakan semakin tingginya minat lulusan SMU sederajat untuk dapat diterima di program ekstensi. Permasalahan lain adalah jam kerja dari para pegawai akademik yang cukup panjang, di mana pegawai yang ada di program ekstensi terdiri dari PNS dari Fakultas Ekonomi sendiri yang diperbantukan di Program Ekstensi Fakultas Ekonomi serta pegawai kontrak. Untuk PNS yang diperbantukan di program ekstensi ini bekerja dari mulai pagi hari di Fakultas Ekonomi yang kemudian melanjutkan sore hari di Program Ekstensi. Dengan demikian, pelayanan akademik hanya bisa dilakukan sore hari, sedangkan untuk pegawai kontrak hanya merupakan pegawai bagian keuangan dan pembantu umum.

Berdasarkan latar belakang tersebut, maka rumusan masalah dalam penelitian ini adalah: 1) bagaimana kualitas pelayanan yang diberikan oleh Program Ekstensi Fakultas Ekonomi Universitas Jambi, 2) bagaimana kepuasan mahasiswa terhadap kualitas pelayanan yang diberikan oleh Program Ekstensi Fakultas Ekonomi Universitas Jambi, 3) apakah kualitas pelayanan berpengaruh terhadap kepuasan mahasiswa di Program Ekstensi Fakultas Ekonomi Universitas Jambi. Tujuan penelitian ini adalah untuk memperoleh bukti empiris pengaruh kualitas pelayanan terhadap kepuasan mahasiswa di Program Ekstensi Fakultas Ekonomi Universitas Jambi.

\section{Pengaruh Kualitas Pelayanan dan Kepuasan Mahasiswa}

Sebagai organisasi yang beroperasi di sektor pendidikan yang bersaing satu sama lain dengan pelayanan yang ditawarkan. Mempelajari pelayanan yang diberikan kepada seluruh pemangku kepentingan merupakan pertimbangan penting. Sekarang organisasi berusaha untuk mengevaluasi layanan yang diberikan oleh organisasi tersebut dan membandingkan layanan ini dengan pesaing untuk menentukan status keunggulan kompetitif. Untuk menjadi organisasi yang kompetitif, mengevaluasi kualitas layanan yang ditawarkan kepada semua pemangku kepentingan. Untuk melihat kualitas layanan yang ditawarkan di sektor pendidikan, model kualitas pelayanan yang diberikan oleh Parasurman et al. (1988) diterima secara luas. Deming (2000) sektor pendidikan harus menerapkan konsep kualitas pelayanan sebagai manufaktur dan pelayanan sektor ekonomi.

Mahasiswa merupakan salah satu stakeholder yang paling penting dari kualitas pendidikan. Untuk memenuhi kepuasan mahasiswa merupakan salah satu tujuan utama di bidang pendidikan. Kepuasan mahasiswa adalah sumber keunggulan kompetitif dan sumber word of mouth pemasaran untuk lembaga pendidikan. Kepuasan mahasiswa di bidang pendidikan mungkin disebabkan penyediaan kualitas pelayanan di institusi. Untuk melihat apa yang memenuhi kepuasan mahasiswa, kualitas pelayanan lembaga harus diukur. Untuk ukuran model kualitas SERVQUAL mungkin pilihan yang terbaik, karena diterima dan digunakan secara luas.

Kandampully (2000) menyatakan bahwa kualitas layanan memiliki peran yang sangat penting bagi kesuksesan bisnis jasa. Dalam bisnis jasa, interaksi konsumen dengan penyedia jasa sangat tinggi, mengingat pada sebagian besar bisnis jasa, pelanggan dituntut keterlibatan dan partisipasinya dalam proses produksi dan konsumsi. Dengan demikian, pelanggan memiliki kesempatan untuk menilai secara kritis kualitas jasa yang disediakan. Pelanggan akan menilai kualitas pelayanan dengan membandingkan antara pelayanan yang diperoleh dengan pelayanan yang diharapkan. Karena itu, kualitas jasa memainkan peran penting dalam memberi nilai tambah terhadap pengalaman jasa secara keseluruhan (Tampubolon et al, 2007).

Model kualitas layanan terdiri tentang lima dimensi yang adalah, tangibles, reliability, responsiveness, assurance, dan empathy. Dimensidimensi kualitas layanan secara luas diterima dan digunakan oleh peneliti dalam berbagai industri.

Berbagai peneliti telah memberikan temuan mengenai perhatian mahasiswa terhadap kualitas dan 
penggunaan siswa untuk mengukur kualitas layanan yang disediakan. Mahasiswa harus dinilai sebagai produk dalam suatu institusi (Emery et al, 2001).

Penelitian telah menegaskan bahwa kualitas pelayanan merupakan faktor pendukung kepuasan (Cronin dan Taylor, 1992; Shemwell et al, 1998). Kualitas pelayanan dianggap penting oleh berbagai peneliti untuk digunakan dalam sektor pendidikan.

Athiyaman (1997) menemukan bahwa ada hubungan yang kuat antara kualitas pelayanan dan kepuasan pelanggan dan semua pertemuan layanan harus dikelola dalam rangka meningkatkan kepuasan konsumen. Ahmed et al. (2010) berpendapat bahwa bahwa ada hubungan positif dan signifikan antara kualitas layanan yang disediakan dan kepuasan pelanggan.

Veloutsou et al. (2004) menemukan bahwa mahasiswa merupakan kriteria utama untuk pemilihan mutu pendidikan dan pelayanan yang diberikan di universitas.

Penelitian terdahulu yang pernah dilakukan adalah penelitian tentang penilaian kualitas jasa pada sekolah bisnis yang dilakukan oleh Pariseau dan McDaniel (1997). Penelitian ini dilakukan pada dua universitas di daerah North-East Region USA. Studi ini membandingkan antara harapan dan persepsi mahasiswa terhadap kualitas pelayanan yang diberikan oleh sekolah bisnis, yang meliputi pelayanan dosen, materi yang diberikan dan pelayanan non akademik. Dalam penelitian ini digunakan lima variabel seperti yang dikemukakan oleh Parasuraman yaitu variabel tangibles, reliability, empathy, responsiveness dan assurance, temuan penelitian ini menunjukkan bahwa mahasiswa menilai bahwa sekolah bisnis harus memiliki tingkat assurance/jaminan yang tinggi kemudian baru diikuti oleh variabel responsiveness, hal ini juga telah sesuai dengan persepsi manajemen sekolah bisnis.

Lee et al. (2000) juga telah melakukan penelitian yang sama namun pada objek yang berbeda, yaitu pada perusahaan entertainment, kursus aerobik dan perusahaan jasa investasi. Hasil penelitiannya menemukan bahwa variabel tangibility merupakan factor yang penting pada industri berbasis peralatan dan responsiveness pada industri berbasis manusia.

Penelitian lainyang dilakukan oleh Sureshchandar et al. (2002) menemukan adanya hubungan yang sangat erat antara kualitas pelayanan dengan tingkat kepuasan pelanggan, semakin baik kualitas pelayanan maka besar kemungkinan konsumen akan semakin puas.

Pada penelitian Dimyati (2002) menunjukkan bahwa 1) penerapan kualitas pendidikan di Fakultas Ekonomi Universitas Jember memiliki kesenjangan antara harapan mahasiswa dengan persepsi manajemen mengenai kualitas jasa pelayanan, 2) terdapat kesenjangan antara harapan mahasiswa dengan persepsi manajemen mengenai kualitas jasa, khususnya untuk dimensi bukti fisik (tangibles), daya tanggap (responsiveness), dan empati (empathy), 3) terdapat kesenjangan antara harapan penguna lulusan dengan persepsi manajemen mengenai kualitas jasa, untuk kelima dimensi jasa (bukti fisik, kehandalan, daya tanggap, jaminan, dan empati.

Penelitian yang dilakukan oleh Duggirala et al. (2008) tentang service quality di India mengenai pengukuran persepsi konsumen pada pusat kesehatan. Penelitian yang dilakukan peneliti melihat obyek penelitian pada Pemadam kebakaran. Pelayanan yang diberikan pada industri jasa dapat diukur dengan service quality yang terdiri atas tangibles (kemampuan perusahaan dalam menunjukkan eksistensi kepada pihak eksternal), reliability (kemampuan perusahaan untuk memberikan pelayanan sesuai yang dijanjikan secara akurat dan percaya), responsiveness (suatu kemauan untuk membantu dan memberikan pelayanan yang cepat dan tepat kepada pelanggan, dan penyampaian informasi yang jelas oleh karyawan perusahaan), assurance (kemampuan karyawan perusahaan dalam memberikan pengetahuan, kesopansantunan, dan kemampuan para pegawai perusahaan untuk menumbuhkan rasa percaya para pelanggan), empathy (karyawan memberikan perhatian yang tulus dan bersifat individual atau pribadi yang diberikan kepada para pelanggan dengan berupaya memahami keinginan konsumen). Pengukuran kepuasan konsumen perlu dilakukan oleh perusahaan karena akan memberikan umpan balik bagi perusahaan dan masukan bagi keperluan pengembangan perusahaan.

Tenaga pendidik (tangibles), metode pengajaran (responsiveness dan keandalan) dan administrasi universitas mengarah pada kepuasan mahasiswa (Navarro et al, 2005). Manajemen universitas harus fokus pada layanan kualitas, informasi dan fasilitas untuk meningkatkan kepuasan mahasiswa, dan kualitas layanan adalah paling penting dari semua (Helgesen dan Nesset, 2007). Kepuasan mahasiswa 
mencerminkan persepsi layanan perbedaan kualitas yang ditawarkan (Gruber et al, 2010). Komunikasi dan responsif faktor-faktor penentu kepuasan mahasiswa yang paling penting, tetapi tidak adanya responsiveness, tangibles, dan komunikasi mengarah ketidakpuasan mahasiswa (Douglas, 2008).

Persepsi kualitas menciptakan citra positif di pikiran siswa yang akhirnya membawa mereka ke kepuasan (Alves dan Raposo, 2010). Mazzarol (1998) mengatakan bahwa lembaga pendidikan tinggi harus memelihara gambar khas untuk memiliki keunggulan kompetitif. Kepuasan pelanggan tergantung pada pelanggan harapan dan persepsi mengenai kualitas pelayanan (Christou dan Sigala, 2002; Cronin dan Taylor, 1992).

Zeithaml et al. (1994) menyatakan bahwa Lima dimensi service quality, sangat berpengaruh terhadap tercapainya satisfaction pelanggan.

\section{METODE}

\section{Metode yang Digunakan}

Metode yang digunakan dalam penelitian ini adalah penelitian deskriptif dan verifikatif. Penelitian deskriptif adalah penelitian yang bertujuan untuk memperoleh deskripsi tentang ciri-ciri variabel keandalan, daya tanggap, bukti fisik, empati, dan jaminan, serta kepuasan mahasiswa. Sifat penelitian verifikatif adalah untuk menguji kebenaran suatu hipotesis yang dilaksanakan melalui pengumpulan data di lapangan, di mana dalam penelitian ini akan menguji pengaruh variabel keandalan, daya tanggap, bukti fisik, empati, dan jaminan terhadap kepuasan mahasiswa di Program Ekstensi Fakultas Ekonomi Universitas Jambi.

\section{Populasi dan Sampel}

Populasi yang digunakan dalam penelitian ini adalah mahasiswa yang terdaftar di Program Ekstensi Fakultas Ekonomi Universitas Jambi pada tahun 2012 yaitu sebanyak 2.154 orang, dengan rincian sebagai berikut: Mahasiswa Program Studi Ilmu Ekonomi dan Studi Pembangunan berjumlah 680 orang, Manajemen 653 orang dan Akuntansi 821 orang. Jumlah sampel sebanyak 100 orang. Dengan metode penarikan sampel yang dipergunakan dalam penelitian ini adalah metode probability sampling dengan teknik stratified sampling.

\section{Metode Analisis Data}

Model persamaan yang akan digunakan dalam penelitian ini adalah model path analysis. Analisis data dalam analisis jalur yang digunakan dalam menguji berapa besarnya sumbangan/kontribusi yang ditunjukkan oleh koefisien jalur pada setiap diagram jalur dari hubungan kausal antar variabel bebas terhadap variabel terikat, dengan melihat nilai $\mathrm{F}$, nilai t dan nilai $\mathrm{R}^{2}$.

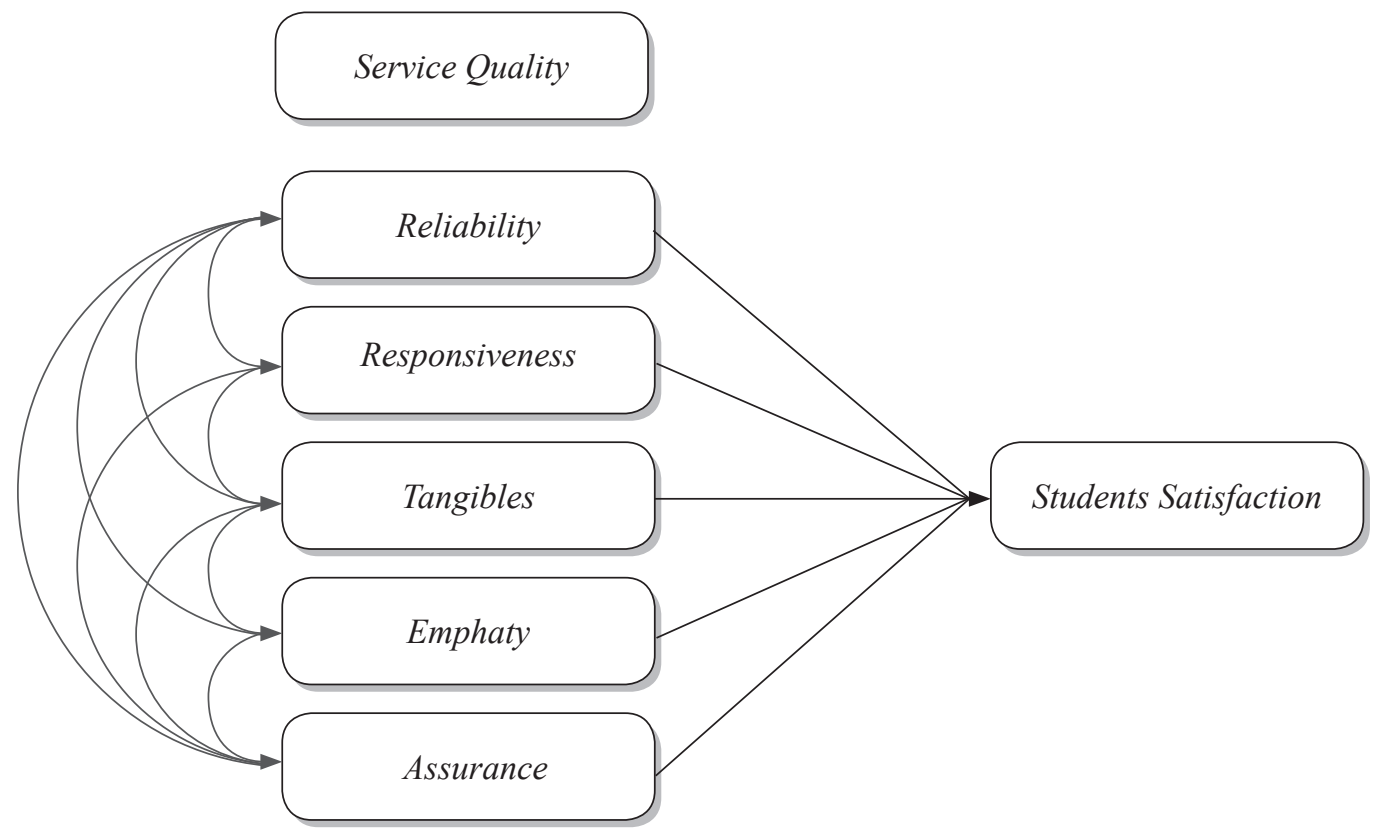

Gambar 1. Model Penelitian 


\section{HASIL}

\section{Deskripsi Penelitian}

\section{Keandalan (Reliability)}

Dalam konteks penelitian ini yang dimaksud dengan variabel keandalan (reliability) adalah kemampuan pegawai dan pengelola Program Ekstensi Fakultas Ekonomi Universitas Jambi dalam memberikan pelayanan yang dijanjikan dengan segera, akurat dan memuaskan. Di mana pelayanan yang diberikan berupa penyediaan peralatan perkuliahan seperti spidol, infokus, pembuatan surat keterangan kuliah, pelayanan perpustakaan dan lain-lain.

Dari Tabel 1. hasil tanggapan responden mengenai variabel keandalan (reliability) dapat dilihat bahwa rata-rata responden memberikan tanggapan cukup baik untuk setiap indikator variabel keandalan (reliability). Ini berarti bahwa secara umum pegawai dan pengelola Program Ekstensi Fakultas Ekonomi Universitas Jambi sudah memberikan pelayanan yang terbaik bagi mahasiswa. Indikator yang relatif rendah berada pada ketepatan waktu kedatangan pegawai dan pengelola program saja yaitu sebesar 3,3 . Hal ini terjadi karena sebagian besar pegawai yang bekerja di Program Ekstensi Fakultas Ekonomi Universitas Jambi merupakan Pegawai Negeri Sipil di lingkungan Fakultas Ekonomi yang memiliki jam kerja dari jam 07.30-16.00 WIB. Sedangkan mahasiswa yang kuliah di Program Ekstensi Fakultas Ekonomi mulai perkuliahan dari jam 11.00-21.00 WIB.

\section{Daya Tanggap (Responsiveness)}

Dalam variabel daya tanggap (responsiveness) terdapat keinginan dari para staf untuk membantu mahasiswa dan memberikan layanan dengan tanggap. Hal ini dapat dilihat dari penerimaan keluhan dan permasalahan yang dihadapi oleh mahasiswa serta penyelesaian terhadap keluhan dan permasalahan tersebut. Tanggapan responden terhadap indikator ini dapat dilihat pada Tabel 2.

Dari Tabel 2. dapat dilihat bahwa mahasiswa beranggapan bahwa daya tanggap (responsiveness) yang diberikan oleh pegawai maupun pengelola Program Ekstensi Fakultas Ekonomi Universitas Jambi sudah merasa cukup baik dengan rata-rata 3,17 dan 3,21. Hal ini berarti setiap keluhan dan permasalahan yang dihadapi oleh mahasiswa akan dicarikan jalan keluar ataupun penyelesaian oleh para pegawai dan pengelola Program. Permasalahan yang sering muncul di kalangan mahasiswa antara lain pada saat melakukan kontrak perkuliahan, ketidak hadiran dosen saat jam perkuliahan, dan kelengkapan bukti pembayaran ataupun kelengkapan berkas akademik.

\section{Bukti Fisik (Tangibles)}

Merupakan fasilitas fisik, perlengkapan, pegawai dan sarana komunikasi yang tersedia di Program Ekstensi Fakultas Ekonomi Universitas Jambi. Indikator pengukuran untuk variabel ini berupa keamanan gedung perkuliahan, ruang kuliah yang memadai, perpustakaan yang nyaman dan lengkap, serta peralatan penunjang perkuliahan. Dari Tabel 3. dapat dilihat tanggapan responden atas variabel bukti fisik yang ada di Program Ekstensi Fakultas Ekonomi Universitas Jambi.

Dari hasil tanggapan responden tersebut dapat terlihat bahwa mahasiswa beranggapan bahwa fasilitas fisik yang dimiliki oleh Program Ekstensi Fakultas Ekonomi Universitas Jambi cukup baik. Kendala yang dihadapi Program Ekstensi dalam melakukan perbaikan terhadap seluruh fasilitas fisik adalah belum adanya lokasi yang sepenuhnya bisa dimiliki oleh Program Ekstensi karena kendala birokrasi yang ada di Universitas Jambi. Sehingga keinginan dari Program Ekstensi untuk memiliki gedung sendiri dengan fasilitas yang lengkap belum bisa diwujudkan.

\section{Empati (Empathy)}

Variabel ini mengindikasikan adanya kemudahan dalam menjalin relasi, komunikasi yang baik, perhatian pribadi dan pemahaman atas kebutuhan pelanggan. Dalam penelitian ini indikator yang dijadikan ukuran dalam menilai variabel empati adalah perhatian yang diberikan oleh pegawai dan pengelola program kepada mahasiswa secara individu dan pemberian rasa aman dan nyaman kepada mahasiswa sewaktu berada di lingkungan kuliah. Tabel 4. merupakan tanggapan responden terhadap variabel empati

Dari Tabel 4. terlihat bahwa variabel empati dianggap cukup baik bagi mahasiswa, artinya adalah pegawai dan pengelola Program Ekstensi Fakultas Ekonomi Universitas Jambi tidak memberikan solusi yang sama atas permasalahan yang dihadapi tiap-tiap mahasiswa, karena rata-rata mahasiswa memiliki permasalahan yang berbeda-beda. 
Tabel 1. Keandalan (Reability)

\begin{tabular}{clccccccc}
\hline & & \multicolumn{1}{c}{ Indikator } & \multicolumn{5}{c}{ Tanggapan Responden } & Rata-Rata \\
\cline { 3 - 6 } No. & & $\mathbf{1}$ & $\mathbf{2}$ & $\mathbf{3}$ & $\mathbf{4}$ & $\mathbf{5}$ & \\
\hline 1. & Ketepatan waktu kedatangan pegawai dan pengelola Program & 10 & 32 & 40 & 14 & 4 & 3,3 \\
2. & Ketepatan waktu pelayanan sesuai dengan yang dijanjikan & 10 & 32 & 43 & 14 & 1 & 3,36 \\
3. & Pemberian pelayanan dengan ramah & 11 & 34 & 37 & 18 & 0 & 3,38 \\
4. & Kesediaan memberikan pelayanan kepada mahasiswa & 10 & 29 & 46 & 14 & 14 & 3,33 \\
\hline
\end{tabular}

Sumber: Data diolah, 2013

Tabel 2. Daya Tanggap (Responsiveness)

\begin{tabular}{clcccccc}
\hline \multirow{2}{*}{ No. } & \multirow{2}{*}{ Indikator } & \multicolumn{5}{c}{ Tanggapan Responden } & \multirow{2}{*}{ Rata-Rata } \\
\cline { 3 - 7 } & & $\mathbf{1}$ & $\mathbf{2}$ & $\mathbf{3}$ & $\mathbf{4}$ & $\mathbf{5}$ & \\
\hline 1. & Tanggap dalam menerima keluhan dan masalah mahasiswa & 6 & 32 & 39 & 19 & 4 & 3,17 \\
2. & Tanggap dalam menyelesaikan keluhan dan permasalahan mahasiswa & 7 & 36 & 34 & 17 & 6 & 3,21 \\
\hline
\end{tabular}

Sumber: Data diolah, 2013

Table 3. Bukti Fisik (Tangibles)

\begin{tabular}{|c|c|c|c|c|c|c|c|}
\hline \multirow{2}{*}{ No. } & \multirow{2}{*}{ Indikator } & \multicolumn{5}{|c|}{ Tanggapan Responden } & \multirow{2}{*}{ Rata-Rata } \\
\hline & & 1 & 2 & 3 & 4 & 5 & \\
\hline 1. & Keamanan gedung Perkuliahan & 4 & 28 & 41 & 21 & 6 & 3,03 \\
\hline 2. & Ruang kuliah yang memadai & 6 & 23 & 32 & 32 & 7 & 2,89 \\
\hline 3. & Laboratorium computer yang nayaman dan lengkap & 6 & 27 & 45 & 21 & 1 & 3,16 \\
\hline 4. & Perpustakaan yang nyaman dan lengkap & 3 & 19 & 38 & 37 & 3 & 2,82 \\
\hline 5. & Peralatan penunjang perkuliahan tersedia untuk semua ruang kuliah & 4 & 30 & 44 & 19 & 3 & 3,13 \\
\hline
\end{tabular}

Sumber: Data diolah, 2013

Table 4. Empati (Emphaty)

\begin{tabular}{|c|c|c|c|c|c|c|c|}
\hline \multirow{2}{*}{ No. } & \multirow{2}{*}{ Indikator } & \multicolumn{5}{|c|}{ Tanggapan Responden } & \multirow{2}{*}{ Rata-Rata } \\
\hline & & 1 & 2 & 3 & 4 & 5 & \\
\hline 1. & $\begin{array}{l}\text { Perhatian diberikan oleh pegawai dan pengelola kepada setiap } \\
\text { mahasiswa secara individu }\end{array}$ & 5 & 13 & 47 & 28 & 7 & 2,81 \\
\hline 2. & Pegawai dan pengelola memberikan rasa aman dan nyaman & 5 & 21 & 55 & 16 & 3 & 3,09 \\
\hline
\end{tabular}

Sumber: Data diolah, 2013

Tabel 5.Variabel Assurance (Jaminan)

\begin{tabular}{|c|c|c|c|c|c|c|c|}
\hline \multirow{2}{*}{ No. } & \multirow{2}{*}{ Indikator } & \multicolumn{5}{|c|}{ Tanggapan Responden } & \multirow{2}{*}{ Rata-Rata } \\
\hline & & 1 & 2 & 3 & 4 & 5 & \\
\hline 1. & Pegawai dan pengelola memberikan pelayanan dengan ramah & 13 & 49 & 36 & 1 & 1 & 3,72 \\
\hline 2. & Pegawai dan pengelola memiliki kompetensi dalam menyelesaikan tugas & 16 & 44 & 38 & 2 & 0 & 3,74 \\
\hline 3. & Kemampuan menyelesaikan permasalahan sesuai dengan waktu yang dijanjikan & 8 & 38 & 43 & 9 & 2 & 3,41 \\
\hline
\end{tabular}

Sumber: Data diolah, 2013 
Tabel 6. Kepuasan Mahasiswa

\begin{tabular}{|c|c|c|c|c|c|c|c|}
\hline \multirow{2}{*}{ No. } & \multirow{2}{*}{ Indikator } & \multicolumn{5}{|c|}{ Tanggapan Responden } & \multirow{2}{*}{$\begin{array}{l}\text { Rata- } \\
\text { Rata }\end{array}$} \\
\hline & & 1 & 2 & 3 & 4 & 5 & \\
\hline 1. & Kepuasan atas layanan yang diterima & 15 & 48 & 27 & 9 & 1 & 3,67 \\
\hline 2. & Kemudahan berinteraksi dengan pegawai dan pengelola & 15 & 47 & 25 & 12 & 1 & 3,63 \\
\hline 3. & Kelengkapan fasilitas pembelajaran & 10 & 46 & 35 & 9 & 0 & 3,48 \\
\hline 4. & Kenyamanan ruang perkuliahan & 6 & 45 & 40 & 9 & 0 & 3,48 \\
\hline 5. & Kelengkapan dan kenyamanan ruang laboratorium komputer dan perpustakaan & 6 & 53 & 27 & 14 & 0 & 3,51 \\
\hline 6. & Kebersihan fasilitas kampus & 8 & 44 & 35 & 13 & 1 & 3,47 \\
\hline 7. & Keramahan pegawai dan pengelola terhadap mahasiswa & 8 & 42 & 36 & 13 & 1 & 3,43 \\
\hline 8. & Terciptanya suasana kekeluargaan di kampus & 5 & 46 & 43 & 6 & 0 & 3,5 \\
\hline 9. & Waktu penyelesaian permasalahan di kampus & 5 & 43 & 45 & 7 & 0 & 3,46 \\
\hline 10. & Rasa aman yang dirasakan saat berada di kampus & 26 & 44 & 27 & 3 & 0 & 3,93 \\
\hline
\end{tabular}

Sumber: Data diolah, 2013

\section{Jaminan (Assurance)}

Variabel assurance (jaminan) mencakup pengetahuan, kompetensi, kesopanan dan sifat dapat dipercaya yang dimiliki para staf; bebas dari bahaya, risiko atau keragu-raguan. Hasil dari tanggapan responden atas variabel assurance dapat dilihat pada Tabel 5.

Dari Tabel 5. terlihat bahwa variabel assurance yang diukur melalui indikator pemberian pelayanan yang ramah, pegawai dan pengelola memiliki kompetensi dalam tugas dan kemampuan menyelesaikan permasalahan sesuai dengan waktu yang dijanjikan berada pada kategori cukup baik. Indikator yang memiliki rata-rata yang paling kecil adalah ketepatan waktu penyelesaian permasalahan sesuai dengan yang dijanjikan, hal ini terjadi karena keterbatasan jumlah pegawai di Program Ekstensi Fakultas Ekonomi Universitas Jambi, di mana jumlah pengelola Program Ekstensi Fakultas Ekonomi Universitas Jambi sebanyak delapan (8) orang dan dibantu oleh tenaga kepegawaian sebanyak 15 (lima belas) orang, yang terdiri atas kepala tata usaha 1 (satu) orang, bagian kemahasiswaan 6 (enam) orang, bagian keuangan 3 (tiga) orang, office boy 3 (tiga) orang dan keamanan 2 (dua) orang. Sedangkan jumlah mahasiswa Program Ekstensi Fakultas Ekonomi
Universitas Jambi per Oktober 2013 sebanyak 2.154 orang.

\section{Kepuasan Mahasiswa}

Kepuasan mahasiswa timbul dariperasaan senang yang dirasakan seseorang dari hasil pengkonsumsian suatu produk, baik barang maupun jasa. Indikator yang digunakan untuk mengukur kepuasan mahasiswa adalah kepuasan atas pelayanan yang diberikan oleh pegawai dan pengelola, puas terhadap kemudahan berinteraksi dengan pegawai maupun pengelola, kelengkapan fasilitas pembelajaran, kenyamanan ruang perkuliahan dan laboratorium komputer dan kelengkapan buku-buku di dalam perpustakaan, kebersihan fasilitas kampus, keramahan pelayanan mahasiswa, suasana kekeluargaan di kampus, kecepatan penyelesaian permasalahan di kampus, dan kepuasan terhadap keamanan saat mahasiswa berada di kampus. Tanggapan responden atas variabel kepuasan mahasiswa dapat dilihat dari Tabel 6.

Dari Tabel 6. terlihat bahwa indikator kepuasan mahasiswa atas rasa aman yang dirasakan saat berada di kampus memiliki rata-rata tertinggi yaitu 3,93 dengan kategori puas. Rasa aman ini dirasakan oleh mahasiswa saat mereka meninggalkan kendaraannya di area kampus, karena ada pegawai yang selalu 
menjaga seluruh kendaraan yang ada di area kampus. Pegawai yang menjaga keamanan kampus bukan hanya bagian keamanan saja, tetapi office boy yang sudah menyelesaikan tugasnya ikut membantu bagian keamanan menjaga kendaran-kendaraan yang ada di kampus, baik itu kendaraan mahasiswa, maupun kendaraan dari pengelola dan dosen-dosen yang mengajar di Program Ekstensi Fakultas Ekonomi Universitas Jambi.

\section{Model Analisis Jalur}

Secara umum analisis jalur variabel keandalan, daya tanggap, bukti fisik, empati, dan jaminan terhadap kepuasan mahasiswa di Program Ekstensi Fakultas Ekonomi Universitas Jambi, untuk lebih jelasnya dapat dilukiskan dalam Gambar 2.

Berdasarkan Gambar 2., maka dapat dijelaskan besaran koefisien jalur dari masing-masing variabel bebas terhadap variabel terikat. Lebih jelasnya lagi, dapat dilihat pada Tabel 7.

Tabel 7. Koefisien Jalur Variabel Keandalan, Daya Tanggap, Bukti Fisik, Empati, dan Jaminan terhadap Kepuasan Mahasiswa

\begin{tabular}{lcc}
\hline \multicolumn{1}{c}{ Variabel } & Koefisien Jalur & $p$-value \\
\hline $\begin{array}{l}\text { Keandalan terhadap kepuasan } \\
\text { mahasiswa }\end{array}$ & 0,201 & 0.049 \\
$\begin{array}{l}\text { Daya tanggap terhadap } \\
\text { kepuasan mahasiswa }\end{array}$ & 0,199 & 0.022 \\
$\begin{array}{l}\text { Bukti fisik terhadap kepuasan } \\
\text { mahasiswa }\end{array}$ & 0,207 & 0.013 \\
$\begin{array}{l}\text { Empati terhadap kepuasan } \\
\text { mahasiswa }\end{array}$ & 0,211 & 0.034 \\
$\begin{array}{l}\text { Jaminan terhadap kepuasan } \\
\text { mahasiswa }\end{array}$ & 0,157 & 0.073 \\
\hline
\end{tabular}

Berdasarkan Tabel 7., maka dapat diperoleh persamaan jalur, sebagai berikut:

$$
\begin{aligned}
\mathrm{Y}= & 0,201 * \mathrm{X} 1+0,199 * \mathrm{X} 2+0,207 * \mathrm{X} 3+0,211 * \mathrm{X} 4 \\
& +0,157 * \mathrm{X} 5+\varepsilon
\end{aligned}
$$

Persamaan tersebut dapat diartikan bahwa: 1) terdapat derajat kontribusi dari variabel keandalan terhadap kepuasan mahasiswa sebesar 0,201; 2) terdapat derajat kontribusi dari variabel daya tanggap terhadap kepuasan mahasiswa sebesar $0,199 ; 3)$ terdapat derajat kontribusi dari variabel bukti fisik terhadap kepuasan mahasiswa sebesar $0,207 ; 4)$ terdapat derajat kontribusi dari variabel empati terhadap kepuasan mahasiswa sebesar 0,211; 5) terdapat derajat kontribusi dari variabel jaminan terhadap kepuasan mahasiswa sebesar 0,157.

Besaran pengaruh total dari variabel keandalan, daya tanggap, bukti fisik, empati, dan jaminan terhadap kepuasan mahasiswa, sebesar 0,542 atau $54,2 \%$, sedangkan pengaruh variabel lain di luar model penelitian adalah sebesar 0,458 atau $45,8 \%$.

Besaran pengaruh parsial dari variabel keandalan (reliability), daya tanggap (responsiveness), bukti fisik (tangible), empati (empathy) dan jaminan (assurance) masing-masing berpengaruh secara sebesar 19,98\%; $23,25 \% ; 25,34 \% ; 21,57 \%$; dan $18,10 \%$.

\section{Pengujian Hipotesis Simultan}

Berdasarkan Tabel 8. terlihat bahwa F-hitung sebesar 22,286 dengan tingkat signifikansi 0,000 jauh lebih kecil dari tingkat alpha 0,05. Dengan demikian, $\mathrm{H}_{0}$ ditolak, sehingga dapat disumpulkan bahwa terdapat pengaruh yang signifikan dari variabel keandalan, daya tanggap, bukti fisik, empati, dan jaminan terhadap kepuasan mahasiswa.

\section{Pengujian Hipotesis Parsial}

Pengujian hipotesis secara parsial untuk variabel keandalan menunjukkan nilai $p$-value (lihat Tabel 7.) sebesar 0,049 lebih kecil dari tingkat alpha 0,05 . Dengan demikian, $\mathrm{H}_{0}$ ditolak, sehingga dapat disumpulkan bahwa terdapat pengaruh yang signifikan dari variabel keandalan terhadap kepuasan mahasiswa. Variabel lainnya, yaitu daya tanggap memiliki nilai $p$-value sebesar 0,022 lebih kecil dari tingkat alpha 0,05 . Dengan demikian, $\mathrm{H}_{0}$ ditolak, sehingga dapat disumpulkan bahwa terdapat pengaruh yang signifikan dari variabel daya tanggap terhadap kepuasan mahasiswa. Hasil perhitungan lainnya menunjukkan bahwa terdapat pengaruh yang signifikan dari variabel bukti fisik terhadap kepuasan mahasiswa $(0,013<0,05)$. Selanjutnya, variabel empati menunjukkan pengaruh yang signifikan terhadap kepuasan mahasiswa dengan nilai nilai $p$-value sebesar 0,034 lebih kecil dari tingkat alpha 0,05. Variabel terakhir, yaitu jaminan tidak berpengaruh secara signifikan terhadap kepuasan mahasiswa $(0,073>0,05)$. 


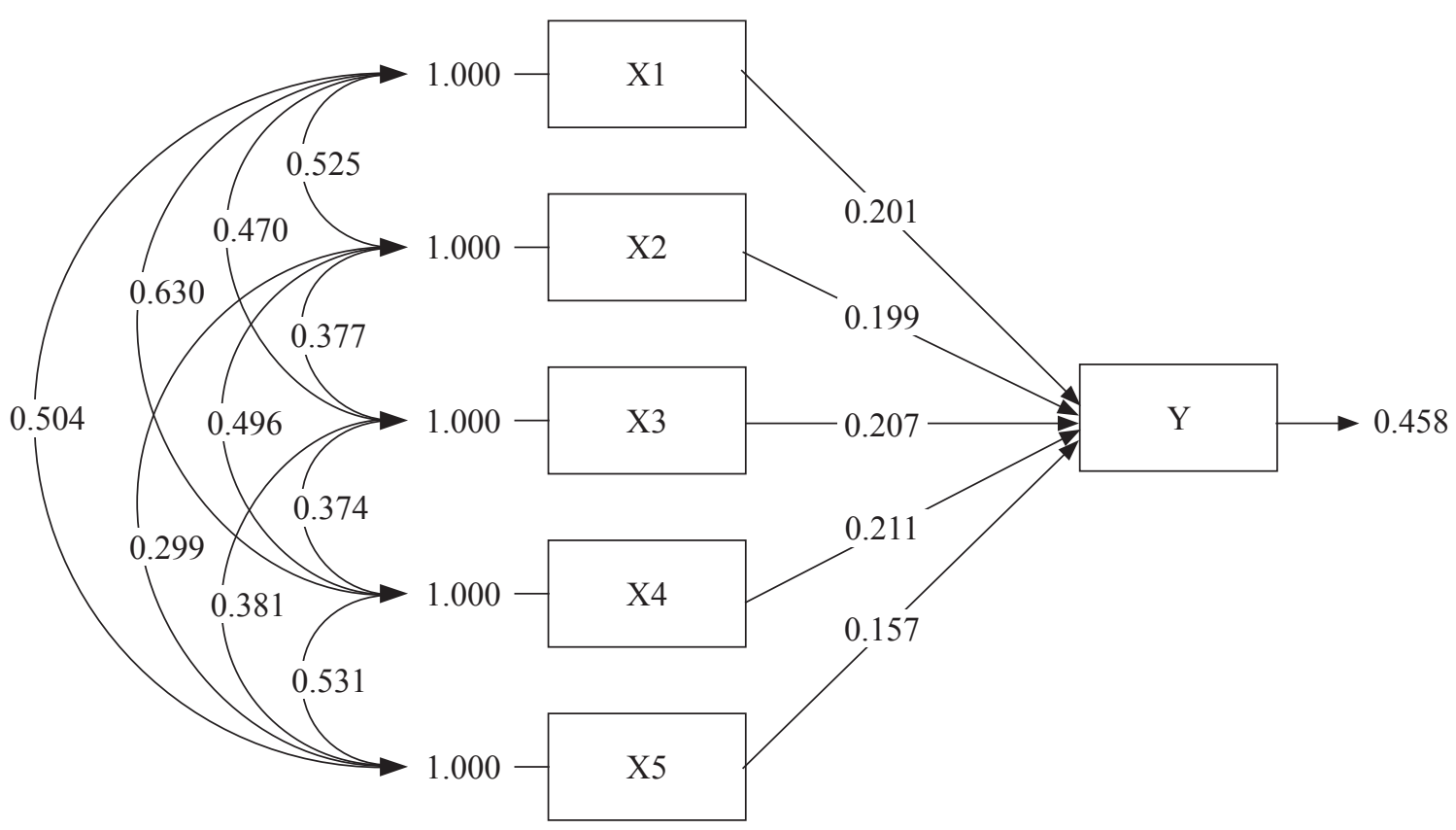

Gambar 2. Model Analisis Jalur

Tabel 8. Hasil Pengujian Hipotesis Simultan

\begin{tabular}{|c|c|c|c|c|c|c|c|c|c|c|}
\hline \multirow[t]{2}{*}{ Model } & \multirow[t]{2}{*}{$\mathbf{R}$} & \multirow[t]{2}{*}{ R Square } & \multirow{2}{*}{$\begin{array}{l}\text { Adjusted } \\
\text { R Square }\end{array}$} & \multirow{2}{*}{$\begin{array}{c}\text { Std. Error } \\
\text { of the Estimate }\end{array}$} & \multicolumn{5}{|c|}{ Change Statistics } & \multirow[t]{2}{*}{ Durbin-Watson } \\
\hline & & & & & $\begin{array}{l}\text { R Square } \\
\text { Change }\end{array}$ & F Change & df1 & df2 & $\begin{array}{l}\text { Sig. F } \\
\text { Change }\end{array}$ & \\
\hline 1 & $.736^{\mathrm{a}}$ & .542 & .518 & .08808 & .542 & 22.286 & 5 & 94 & .000 & 1.925 \\
\hline
\end{tabular}

Sumber: Data diolah, 2013

Tabel 9. Pengaruh secara Parsial

\begin{tabular}{|c|c|c|c|c|c|c|c|c|c|c|}
\hline \multirow{2}{*}{ Model } & \multicolumn{2}{|c|}{$\begin{array}{c}\text { Unstandardized } \\
\text { Coefficients }\end{array}$} & \multirow{2}{*}{$\begin{array}{c}\begin{array}{c}\text { Standardized } \\
\text { Coefficients }\end{array} \\
\text { Beta }\end{array}$} & \multirow{2}{*}{$\mathbf{T}$} & \multirow{2}{*}{ Sig. } & \multicolumn{3}{|c|}{ Correlations } & \multicolumn{2}{|c|}{$\begin{array}{l}\text { Collinearity } \\
\text { Statistics }\end{array}$} \\
\hline & B & Std. Error & & & & Zero-order & Partial & Part & Tolerance & VIF \\
\hline (Constant) & .179 & .055 & & 3.268 & .002 & & & & & \\
\hline Keandalan & .034 & .017 & .201 & 1.998 & .049 & .615 & .202 & .139 & .481 & 2.077 \\
\hline 1 Daya Tanggap & .033 & .014 & .199 & 2.325 & .022 & .534 & .233 & .162 & .662 & 1.512 \\
\hline Bukti Fisik & .040 & .016 & .207 & 2.534 & .013 & .515 & .253 & .177 & .730 & 1.370 \\
\hline Empati & .032 & .015 & .211 & 2.157 & .034 & .597 & .217 & .151 & .508 & 1.967 \\
\hline Jaminan & .027 & .015 & .157 & 1.810 & .073 & .508 & .184 & .126 & .650 & 1.538 \\
\hline
\end{tabular}

a. Dependent Variable: Kepuasan 


\section{PEMBAHASAN}

\section{Pengaruh Kualitas Pelayanan Terhadap Kepuasan Mahasiswa}

Kualitas pelayanan berpengaruh positif dan signifikan terhadap kepuasan mahasiswa. Hal ini berarti bahwa semakin baik kualitas pelayanan yang diberikan oleh Program Ekstensi Fakultas Ekonomi Universitas Jambi, maka mahasiswa semakin merasa puas terhadap layanan tersebut. Hubungan kualitas pelayanan dan kepuasan mahasiswa tidak lepas dari pembicaraan kreativitas layanan program ekstensi. Untuk mewujudkan suatu layanan berkualitas yang bermuara pada kepuasan mahasiswa, program ekstensi harus mampu mengidentifikasi siapa mahasiswanya, sehingga mampu memahami tingkat persepsi dan harapan mahasiswa atas kualitas layanan.

Kepuasan mahasiswa merupakan perbandingan antara persepsi dengan harapan mahasiswa terhadap layanan program ekstensi yang dirasakan mahasiswa. Bila seorang mahasiswa mengharapkan suatu pelayanan pada tingkat tertentu, dan yang dirasakan adalah bahwa pelayanan yang diterima lebih tinggi dari apa yang diharapkannya, maka mahasiswa tersebut dapat dikatakan sangat puas. Demikian pula apabila mahasiswa mengharapkan suatu tingkat pelayanan tertentu, dan pada kenyataannya mahasiswa tersebut merasakan bahwa pelayanan yang diterimanya sesuai dengan harapannya, maka mahasiswa tersebut dapatlah dikatakan puas. Sebaliknya, bila kualitas pelayanan yang diterima lebih rendah dari kualitas pelayanan yang diharapkan, maka mahasiswa tersebut akan dikatakan sebagai mahasiswa yang tidak puas atau kecewa.

Pengelola program ekstensi harus dapat memberikan jasa pelayanan yang bermutu dan lebih baik daripada pesaingnya. Mahasiswa pada dasarnya harus dipuaskan dengan totallitas nilai yang tinggi, bila tidak, maka mahasiswa dapat dengan mudah berpindah ke tempat lain. Karena saat ini mahasiswa dapat dengan mudah berpindah dari satu kampus ke kampus lainnya, yang dapat memberikan kepuasan sesuai dengan tingkat pelayanan yang diinginkannya.

Hasil studi ini juga membuktikan bahwa kajian teoritis dan studi empirik yang menyatakan dan membuktikan adanya hubungan kausalitas yang positif dan signifikan antara kualitas pelayanan dan kepuasan mahasiswa. Hasil studi ini mendukung dan memperkuat hasil studi yang dilakukan oleh peneliti sebelumnya, yaitu Oliver (1981), Parasuraman et al. (1985), Parasuraman et al. (1988), Cronin dan Taylor (1992), Zeithaml et al. (1994), Parasuraman et al. (1996), Zeithaml and Bitner (1996), Athiyaman (1997), McDaniel (1997), Shemwell et al. (1998), Mazzarol (1998), Deming (2000), Lee et al. (2000), Kandampully (2000), Lassar et al. (2000), Holm (2000), Bei and Chian (2001), Emery et al. (2001), Sureshchandar et al. (2002), Dimyati (2002), Christou dan Sigala, (2002), Veloutsou et al. (2004), Navarro et al. (2005), Helgesen dan Nesset, (2007), Tampubolon et al. (2007), Duggirala et al. (2008), Douglas (2008), Ahmed, et al. (2010), Gruber et al, 2010), dan Alves dan Raposo (2010)

Besaran pengaruh parsial menjelaskan bahwa dimensi tangibles sebagai pengukur variabel kualitas layanan adalah yang terbesar. Hal ini sejalan dengan penelitian yang dilakukan oleh Lee et al. (2000) yang menemukan bahwa variabel tangibility merupakan faktor yang penting.

Selanjutnya, besaran pengaruh parsial disusul variabel lain, berturut-turut adalah dimensi responsiveness, empathy, reliability dan assurance. Hal ini berarti bahwa dimensi tangibles lebih mendominasi sebagai pengukur variabel kualitas pelayanan dibandingkan dengan indikator lainnya. Jadi variabel kepuasan mahasiswa dipengaruhi oleh variabel kualitas pelayanan terutama oleh dimensi tangibles, di samping dimensi lainnya seperti responsiveness, empathy, reliability, dan assurance.

Secara parsial, variabel assurance ternyata dinilai tidak berpengaruh secara signifikan terhadap kepuasan pelanggan. Hal ini tidak sejalan dengan penelitian sebelumnya yang dilakukan McDaniel (1997). Hasil temuan penelitiannya menunjukkan bahwa mahasiswa menilai bahwa sekolah bisnis harus memiliki tingkat assurance/jaminan yang tinggi, hal ini juga telah sesuai dengan persepsi manajemen sekolah bisnis.

Penyebab terjadinya hal ini bisa saja berasal dari harapan mahasiswa terhadap dimensi keandalan, daya tanggap, bukti fisik, dan empati adalah suatu 
keharusan bagi sebuah Program Ekstensi Fakultas Ekonomi di Universitas Jambi. Mahasiswa menilai yang bisa membedakan Program Ekstensi Fakultas Ekonomi Universitas Jambi dengan program ekstensi yang lain adalah dari kemampuan memberikan bukti fisik, daya tanggap, empati, dan keandalan dari sebuah program ekstensi terhadap kebutuhan yang diinginkan oleh mahasiswa.

\section{KESIMPULAN}

Kualitas pelayanan pada Program Ekstensi Fakultas Ekonomi Universitas Jambi rata-rata memiliki kategori baik, di mana nilai rata-rata terendah berada pada angka 2,81 dan angka tertinggi berada pada 3,72. Variabel kepuasan rata-rata berada pada kategori puas, di mana nilai terendah pada angka 3,43 dan angka tertinggi berada pada angka 3,93. Kualitas pelayanan berpengaruh signifikan terhadap kepuasan mahasiswa pada Program Ekstensi Fakultas Ekonomi Universitas Jambi secara simultan sebesar $54,2 \%$, sedangkan dimensi dari kualitas pelayanan yang terdiri atas keandalan (reliability), daya tanggap (responsiveness), bukti fisik (tangibles), empati (empathy) dan jaminan (assurance) memberikan pengaruh secara parsial sebesar 19,98\%; 23,25\%; $25,34 \% ; 21,57 \%$; dan $18,10 \%$.

Dimensi kualitas pelayanan yang memiliki nilai terendah sebesar $18,10 \%$ adalah dimensi jaminan (assurance), untuk itu pengelola Program Ekstensi Fakultas Ekonomi harus lebih bisa memberikan jaminan penyelesaian permasalahan yang dihadapi mahasiswa. Pengelola program mempertahankan ataupun meningkatkan dimensi kualitas pelayanan yang tertinggi yaitu dimensi daya tanggap (responsiveness) dengan selalu menyediakan waktu untuk memberikan pelayanan maksimal kepada mahasiswa.

\section{DAFTAR PUSTAKA}

Ahmed, Ishfaq, Muhammad Musarrat Nawaz, Zulfqar Ahmad, Zafar Ahmad, Muhammad Zeeshan Shaukat, Ahmad Usman, Wasim-ul-Rehman, dan Naveed Ahmed. 2010. Does Service Quality Affect Students' Performance? Evidence from Institutes of Higher Hearning. African Journal of Business Management, 4 (12): 2527-2533.
Ahmed, I., Nawaz, M. M., Usman, A., Shaukat, M. Z., Ahmad, N. 2010. Impact of Service Quality on Customer's Satisfaction: Empirical Evidence from Telecom Sector of Pakistan. Interdisciplinary Journal of Contemporary Research in Business, 1 (12): 98-113.

Alves, H. dan Raposo, M. 2010. The Influence of University Image on Students Behavior. International Journalof Educational Management, 24 (1): 73-85.

Athiyaman, A. 1997. Linking Student Satisfaction and Service Quality Perceptions: The Case of University Education. European Journal Marketing. 31 (7): 528-540.

Bei, Lien-T. and Chiao, Yu-Ching. 2001. An Integrated Model for The Effects of Perceived Product, Perceived Service Quality, and Perceived Price Fairness on Consumer Satisfaction and Loyalty. Journal of Consumer Satisfaction, Dissatisfaction and Complaining Behavior, 14: 125-141.

Christou. E. dan Sigala, M. 2002. Conceptualizing The Measurement of Service Quality and TQM Performance for Hotels: The HOSTQUAL model. Acta Touristica, 14(2): 140-169.

Cronin, J. J. Jr., dan Taylor, S. A. 1992. Measuring Service Quality: a Reexamination and Extension. Journal Marketing, 56 (3): 55-68.

Deming, W. E. 2000. The New Economics: For industry Government, Education. Cambridge: MIT Press.

Dimyati M. 2002. Analisis Kesenjangan Antara Harapan Dengan Persepsi Atas Kualitas Jasa Pendididkan Tinggi: Kasus di FE Universitas Jember Surabaya. Jurnal Riset Ekonomi dan Manajemen, 1 (1).

Douglas, J., McClelland, R., dan Davies, J. 2008. The Development of a Conceptual Model of Student Satisfaction with Their Experience in Higher Education. Quality Assurance Education, 16 (1): 19-35.

Duggirala, Mayuri, Chandrasekharan Rajendran, dan R. N. Anantharaman. 2008. Patient-Perceived Dimensions of Total Quality Service in Healthcare. Benchmarking: An International Journal, 15 (5): 560-583.

Emery, C. Kramer, T. dan Tian, R. 2001. Customer vs. Product: Adopting an Effective Approach to Business Students. Quality Assurance Education, 9 (2): 110-115. 
Fitzsimmons, J. A. dan Fitzsimmons, M. J. 2004. Service Management: Operations, Strategy, and Information Technology (4 $4^{\text {th }}$ edition). New York: Irwin McGraw-Hill.

Fornell, C. 1992. A National Customer Satisfaction Barometer: The Swedish Experience. Journal of Marketing, 56 (2): 7-18.

Gruber, T., Fub, S., Voss, R., dan Glaser-Zikuda, M. 2010. Examining sSudent Satisfaction with Higher Education Services Using A New Measurement Tool. International Journal of Public Sector Management, 23 (2): 105-123.

Holm, Mats G. 2000. Service Quality and Product Quality in Housing Refurbishment. The International Journal of Quality \& Reliability Management, 17: 527-542.

Helgesen, O., dan Nesset, E. 2007. What Accounts for Students' Loyalty? Some Field Study Evidence. International Journal of Educational Management, 21 (2): 126-143.

Kandampully, J. 2000. The Impact of Demand Fluctuation on the Quality of Service: A tourism Industry Example. Managing Service Quality, 10 (1): 10-18.

Lassar, Walfried M., Chris M. and Winsor, Robert D. 2000. Service Quality Perspectives and Satisfaction in Private Banking. The International Journal of Bank Marketing, 18: 181-211.

Lee, Hasik, Yongki Lee, dan Dongkeun Yoo. 2000. The Determinants of Perceived Service Quality and Its Relationship with Satisfaction. Journal of Services Marketing, 14 (3): 217-231.

Mazzarol, T. 1998. Critical Success Factors for International Education Marketing. International Journal of Educational Management, 12 (4): 163-75.

Navarro, M. M., Iglesias, M. P., Torres, P. R. 2005. Measuring Customer Satisfaction in Summer Courses. Quality Assurance Education, 13 (1): 53-65.

Oliver R. L. 1981. Measurement and Evaluation of Satisfaction Process in Retail Setting. Journal of Retailing, 57: 25-48.

Olorunniwo, F., Maxwell K. Hsu., dan Godwin J. Udo. 2006. Service Quality, Customer Satisfaction, and Behavioral Intentions in the Service Factory. Journal of Services Marketing, 20 (1): 59-72.

Parasuraman, V., A. Zeithaml dan L. L. Beny. 1985. A Conceptual Model of Service Quality and its Implication for Future Research. Journal of Marketing Research, 49: 41-50.
Parasuraman, V., A. Zeithaml dan L. L. Beny. 1988. Servqual A. Multiple Item for Measuring Customer Perception of Service Quality. Journal of Retailing, 64 (1): 12-40.

Parasuraman, V., A. Zeithaml dan L. L. Beny. 1996. The Behavioral Consequences of Service Quality. Journal of Marketing, 40: 31-46.

Pariseau, Susan E. dan McDaniel, J. R. 1997. Assesing Service Quality in Schools of Business. International Journal of Quality \& Reliability Management. 14 (3): 204-218.

Prince, J. T. dan Daniel H. Simon. 2009. Multimarket Contact and Service Quality: Evidence from Ontime Performance in the U.S. Airline Industry. Academy of Management Journal, 52 (2): 336-354.

Seniati, Liche. 2006. Pengaruh Masa Kerja, Trait Kepribadian, Kepuasan Kerja, dan Iklim Psikologis Terhadap Komitmen Dosen Pada Universitas Indonesia, Makara, Sosial Humaniora, 10 (2): 88-97.

Shemwell, D. J., Yavas, U., dan Bilgin, Z. 1998. Customer Service Provider Relationship: an Empirical Test of A Model of Service Quality, Satisfaction and Relationship Oriented Outcomes. International Journal Service Industry Management, 9 (2): 155-168.

Sureshchandar, G. S., Chandrasekharan Rajendran, dan R. N. Anantharaman. 2002. The Relationship Between Service Quality and Customer Satisfaction: A Factor Specific Approach. Journal of Services Marketing, 16 (4): 363-379.

Tampubolon, Maria, Perdani Sukmaningrum, dan Serli Wijaya. 2007. Analisa Kepuasan Senior Market Terhadap Kualitas Layanan di Hotel Bintang 4 dan Bintang 5 di Surabaya. Jurnal Manajemen dan Kewirausahaan, 9 (2): 135-143.

Veloutsou, C., Lewis, J. W., Paton, R. A. 2004. University Selection: Information Requirements and Importance. International Journal of Educational Management, 18 (3): 160-171.

Zeithaml, Valarie, A., Berry, L. dan Parasuraman, A. 1994. The Behavioral Consequences of Service Quality. Journal of Marketing, 60: 31-46.

Zeithaml, Valerie A., and Bitner, Mary Jo. 1996. Services Marketing. ( $1^{\text {st }}$ edition). New York: McGrawHill. 